\title{
Analisis Potensi Perekonomian Pedagang Kaki-Lima di Kota Langsa
}

\section{The Economic Potential Analysis of the Street Vendors in Kota Langsa}

\author{
Iskandar Budiman \\ Fakultas Ekonomi dan Bisnis Islam, IAIN Langsa, Kota Langsa \\ e-mail korespondensi: iskandarbudiman@iainlangsa.ac.id
}

\begin{tabular}{|c|c|}
\hline Into & Abstrak \\
\hline sember 2020 & $\begin{array}{l}\text { Artikel ini bersumber dari hasil penelitian, terfokus pada aktivitas para pedagang } \\
\text { jajanan yang ada di sepanjang Jalan Cut Nyak Dhien Kota Langsa. Terdapat } \\
\text { lebih dari } 70 \text { (tujuh puluh) pedagang kaki-lima dengan berbagai jenis barang } \\
\text { dagangannya. Penelitian ini bertujuan untuk mengetahui peran sektor informal }\end{array}$ \\
\hline $\begin{array}{l}\text { Nomor DOI } \\
\text { 10.33059/jseb.v12i2.3043 } \\
\text { Cara Mensitasi : } \\
\text { Budiman, I. (2021). Analisis } \\
\text { potensi perekonomian } \\
\text { pedagang kaki-lima di Kota } \\
\text { Langsa. Jurnal Samudra } \\
\text { Ekonomi dan Bisnis, 12(2), } \\
\text { 184-199. doi: } \\
\text { 10.33059/jseb.v12i2.3043. }\end{array}$ & $\begin{array}{l}\text { kerja, prospek pengembangan usaha wisata kuliner terhadap pertumbuhan } \\
\text { ekonomi keluarga, serta penambahan sumber pendapatan asli daerah melalui } \\
\text { pengutipan retribusi. Data diperoleh melalui observasi, wawancara dan } \\
\text { dokumentasi, dan selanjutnya diolah menggunakan teknik deskriptif analisis. } \\
\text { Hasil analisis menunjukkan bahwa pedagang kaki-lima di kawasan kota menjadi } \\
\text { alternatif pekerjaan populer. Kondisi ini bersinergi dengan program pemerintah } \\
\text { yang menata kawasan jajanan tersebut sebagai sentra wisata kuliner dan sangat } \\
\text { membantu pedagang untuk meningkatkan pendapatan keluarga, juga telah } \\
\text { memberi dampak terhadap meningkatnya pengunjung dan bertambahnya } \\
\text { pendapatan dari retribusi. }\end{array}$ \\
\hline
\end{tabular}

Kata Kunci: Potensi Ekonomi, Pedagang Kaki-Lima, Kota Langsa.

\begin{tabular}{|c|c|}
\hline Article Info & Abstract \\
\hline $\begin{array}{l}\text { Article History: } \\
\text { Received: } 06 \text { December } 2020 \\
\text { Accepted: } 16 \text { February } 2021 \\
\text { Published: July } 2021\end{array}$ & $\begin{array}{l}\text { This article is based on the results of research, focused on the activities of } \\
\text { hawker traders along Cut Nyak Dhien Street, Langsa City. There are more than } \\
\text { seventy street vendors with various types of merchandise. The research aims to } \\
\text { determine the role of the informal sector street vendors of economically weak }\end{array}$ \\
\hline $\begin{array}{l}\text { DOI Number: } \\
\text { 10.33059/jseb.v12i2.3043 } \\
\text { How to cite: } \\
\text { Budiman, I. (2021). Analisis } \\
\text { potensi perekonomian } \\
\text { pedagang kaki-lima di Kota } \\
\text { Langsa. Jurnal Samudra } \\
\text { Ekonomi dan Bisnis, } 12(2), \\
\text { 184-199. doi: } \\
\text { 10.33059/jseb.v12i2.3043. }\end{array}$ & $\begin{array}{l}\text { groups in obtaining employment, the prospect of developing a culinary tourism } \\
\text { business on family economic growth, and additional sources of local revenue. } \\
\text { Data obtained through observation, interviews and documentation, and then } \\
\text { processed using descriptive analysis techniques. The analysis results showed } \\
\text { that street vendors in urban areas are a popular alternative to work. This } \\
\text { condition is in synergy with the government program that arranges this area as } \\
\text { a center for culinary tourism and is very helpful for traders to increase family } \\
\text { income, as well as having an impact on increasing visitors and increasing local } \\
\text { income. }\end{array}$ \\
\hline
\end{tabular}

Keywords: Economic Potential, Street Vendors, Langsa City. 


\section{PENDAHULUAN}

Aktivitas perekonomian dalam wilayah perkotaan menjadi magnit bagi masyarakat luas dan merupakan bagian yang tidak bisa dipisahkan dalam kehidupan manusia seharihari. Kebutuhan akan sandang dan pangan harus dipenuhi setiap harinya. Perekonomian suatu masyarakat juga memiliki peranan yang penting untuk mengukur kestabilan suatu bangsa dan negara. Tingkat pertumbuhan dan pembangunan suatu negara juga dapat dilihat dari level pertumbuhan ekonomi masyarakatnya. Umumnya pertumbuhan ekonomi dalam perkotaan disebabkan adanya kelemahan dari sistem ekonomi tradisional yang mengabaikan dimensi lokasi dan ruang. Disamping itu, ilmu ekonomi relatif menganggap bahwa struktur ekonomi wilayah dan perkotaan adalah sama dengan struktur ekonomi nasional (Prastowo, 2016).

Pembangunan ekonomi didefinisikan sebagai peningkatan pendapatan per kapita masyarakat yaitu tingkat pertambahan Gross Domestic Product (GDP) pada satu tahun tertentu melebihi pertambahan penduduk (Egerer et al., 2016). Dalam konsep ilmu ekonomi, pembangunan bisa diartikan sebagai suatu proses pertumbuhan ekonomi yang berkesinambungan, dimana sebahagian besar masyarakat beralih dari taraf kehidupan yang miskin menuju kehidupan yang lebih baik (Berger et al., 1997).

Dinamika pembangunan perekonomian saat ini berdampak pada sektor perekonomian yang cenderung lebih modern. Pusat-pusat perbelanjaan berbentuk gedung-gedung tinggi bermunculan. Toko-toko supermarket selaku pengganti toko kelontong bersifat tradisional bermunculan baik di perkotaan maupun di pedesaan. Restoran-restoran berskala besar dan franchise kuliner luar negeri juga menjadi tempat "berkumpul" selain bersantap yang digemari masyarakat Indonesia. Hal tersebut seakan menjadi simbol sebuah gaya hidup yang modern (Zaman, 2017).

Kawasan perdagangan merupakan salah satu sektor informal yang mampu diangkat sebagai tempat keinginan untuk menghasilkan pendapatan pada suatu masyarakat. Kawasan perdagangan atau pasar pada masyarakat mempunyai peran penting yaitu sebagai pusat ekonomi maupun pusat kebudayaan. Sebagai pusat kegiatan ekonomi, pasar merupakan tempat bertemunya produsen dan konsumen. Pada bidang distribusi, pasar mempunyai peranan menyebarluaskan barang-barang hasil produksi yang dibutuhkan oleh masyarakat; sedangkan pada bidang konsumsi, pasar berperan menyediakan kebutuhan pokok dan kebutuhan tambahan lainnya (Aliyah, 2017).

Di sisi lain, para pedagang kaki-lima dengan berbagai barang dagangan berjuang dalam memperoleh pendapatan dengan modal yang tentunya lebih rendah, tidak terorganisir dan ilegal. Bagi kelompok ekonomi lemah, sektor informal ini laksana pahlawan karena dapat dijadikan sebagai sumber utama dan/ atau alternatif pendapatan. Sejak akumulasi penduduk di kota-kota baik besar maupun kecil, tidak dapat tercakup dalam peluang kerja formal yang ada, penduduk yang tidak mampu berkompetisi di sektor informal. Termasuk dalam di kelompok ini adalah penduduk dengan derajat pendidikan serta keterampilan yang rendah, korban tindakan penggusuran, kaum perempuan, dan modal kecil (Wijayaningsih, 2018).

Dalam proses pembangunannya, peran pemerintah kota maupun daerah sangat besar dan menentukan, disamping juga diperlukan peran masyarakat yang bersifat partisipatif dalam rangka mencapai tujuan pembangunan kota yang berkelanjutan. Serupa halnya pada pembangunan perekonomian di Kota Langsa, menuju kota yang modern tentunya tidaklah terlepas dari perkembangan perekonomian kotanya. Kehadiran dari sejumlah tempat atau 
lokasi perbelanjaan modern baik skala kecil seperti Indomaret, Alfamart, Mart 212 dan supermarket serta minimarket, membuktikan bahwa gaya konsumsi masyarakat dilatarbelakangi oleh sisi modern dan gaya hidup yang kian konsumtif (Safuwan, 2007).

Di sisi lain, sektor informal di kota ini terlihat masih bertahan khususnya dengan pedagang-pedagang kaki-lima dari berbagai umur. Salah satunya adalah pedagang kakilima di sepanjang Jalan Cut Nyak Dhien Kota Langsa. Setiap harinya transaksi cash money selalu terjadi di kawasan ini, walaupun ada beberapa yang berjualan dengan menu yang sama namun tidak menyurutkan langkah kaki konsumen untuk terus melakukan transaksi secara tunai.

Berdasarkan observasi awal, peneliti menemukan bahwa mayoritas pedagang kakilima tersebut terlihat masih usia muda dengan range usia sekitaran 17-40 tahun. Menjadi pedagang kaki-lima dilakukan untuk mencari atau menambah penghasilan sehari-hari serta untuk memajukan perekonomian keluarga. Mereka kreatif, rajin, dan pantang menyerah berusaha agar bisa survive dalam berbagai kondisi perekonomian.

Selain bisa berperan mengurangi tingkat pengangguran khususnya pada kelompok usia produktif, para pedagang kaki-lima ini juga berjasa untuk pemasukan retribusi di Kota Langsa. Kegiatan pedagang kaki-lima yang merupakan jenis usaha perdagangan sektor informal perlu diberdayakan guna menunjang pertumbuhan perekonomian masyarakat dan sekaligus sebagai salah satu pilihan dalam penyediaan dagangan yang dibutuhkan oleh masyarakat dengan harga terjangkau. Hal ini sesuai dengan Maqashid al-Syariah yang menghendaki tercapainya suatu mashlahah, sehingga secara logis konsep ini juga concern menghindari kondisi kategori sulit (mafsadah) (Nasution, 2016).
Berdasarkan urgensi permasalahan dan analisis yang telah diuraikan, maka peneliti ingin menganalisis lebih mendalam mengenai kebangkitan ekonomi khususnya terhadap pedagang kaki-lima yang menjadikan Kota Langsa sebagai kota bebas pengangguran, kekinian di dalam pengelolaan pendapatan daerah dengan melakukan penggalian pada potensi-potensi lokal, dimana kebangkitan ekonomi dinilai dapat mengatasi problem perekonomian yang paling mendasar, yaitu pengangguran dan kemiskinan.

\section{Pedagang Kaki-Lima dan Perekonomian Masyarakat}

Pedagang kaki-lima atau disingkat PKL merupakan istilah untuk menyebut penjaja dagangan yang melakukan kegiatan komersial di atas daerah milik jalan (DMJ/trotoar) yang (seharusnya) diperuntukkan bagi pejalan kaki (pedestrian). Istilah pedagang kaki-lima pertama kali dikenal pada zaman Hindia Belanda, tepatnya saat Gubernur Jenderal Stanford Raffles berkuasa. Ia mengeluarkan peraturan yang mengharuskan pedagang informal membuat jarak sejauh 5 kaki atau sekitar 1,2 meter dari bangunan formal di pusat kota (Ersina et al., 2017). Peraturan ini diberlakukan untuk melancarkan jalur pejalan kaki sambil tetap memberikan kesempatan kepada pedagang informal untuk berdagang. Tempat pedagang informal yang berjarak 5 (lima) kaki dari bangunan formal di pusat kota inilah yang kelak dikenal dengan dengan "kaki-lima", dan pedagang yang berjualan pada tempat tersebut dikenal dengan sebutan "pedagang kaki-lima" atau PKL (Yunus \& Insani, 2017).

Pada tahap berikutnya, para pedagang kaki-lima inilah yang menjadi salah satu penggerak tumbuhnya tingkat perekonomian masyarakat. Secara umum, pertumbuhan ekonomi didefinisikan sebagai peningkatan kemampuan dari suatu perekonomian dalam 
memproduksi barang dan jasa. Pertumbuhan ekonomi merupakan salah satu indikator yang sangat penting dalam melakukan analisis tentang pembangunan ekonomi yang terjadi pada suatu negara. Pertumbuhan ekonomi menunjukkan sejauh mana level aktivitas perekonomian akan menghasilkan tambahan pendapatan masyarakat pada suatu periode tertentu. Hal ini karena secara mendasar aktivitas perekonomian merupakan proses penggunaan faktor-faktor produksi untuk menghasilkan output, maka proses ini pada gilirannya akan menghasilkan suatu aliran balas jasa terhadap faktor produksi yang dimiliki oleh masyarakat. Dengan adanya pertumbuhan ekonomi maka diharapkan pendapatan masyarakat sebagai pemilik faktor produksi juga meningkat (Parimin \& Putra, 2018).

Pertumbuhan ekonomi sebagai kenaikan produksi jangka panjang adalah kemampuan suatu negara dalam menyediakan semakin banyak jenis barang-barang ekonomi kepada penduduknya. Faktor utama yang dinilai mempengaruhi pertumbuhan perekonomian adalah ketersediaan sumber daya alam. Tanah sebagaimana basic resource dalam ilmu ekonomi mencakup sumber daya alam seperti kesuburan tanah, letak dan susunannya, kekayaan hutan, mineral, iklim, sumber air, sumber lautan dan lain sebagainya. Dalam pertumbuhan ekonomi, tersedianya sumber daya alam secara melimpah merupakan hal yang penting. Faktor pertumbuhan ekonomi ini sangat dipengaruhi oleh tingkat kemajuan teknologi, penyesuaian kelembagaan serta ideologis yang bersifat non-ekonomi (Arsyad, 2015).

Faktor non-ekonomi bersama sektor ekonomi selanjutnya saling mempengaruhi kemajuan perekonomian. Faktor sosial dan budaya juga mempengaruhi pertumbuhan ekonomi, seperti pendidikan dan kebudayaan yang menanamkan semangat untuk selalu menghasilkan berbagai penemuan baru, juga merubah cara pandang, harapan, struktur, dan nilai-nilai sosial. Sumber daya manusia adalah faktor terpenting dalam pertumbuhan ekonomi. Faktor politik dan pengelolaan administratif yang tertata baik dinilai sangat membantu pertumbuhan ekonomi modern (Syahputra, 2017).

\section{Peran Pemerintah dalam Perekonomian}

Pemerintah Kota Langsa memiliki peran penting dan sebagai policy maker dalam pengembangan perekonomian yang berbasis kearifan lokal dengan memiliki dasar rasionalitas yang kokoh. Menurut perspektif Islam, pemerintah memegang peran penting terhadap perekonomian umat yang didasari pada argumentasi (Hanifullah, 2012), bahwa: (a) Pemerintah wujud dari derivasi konsep kekhalifahan (khilafah)' (b) Konsekuensi adanya kewajiban-kewajiban kolektif (fard al-kafiyah); serta, (c) Adanya kegagalan pasar dalam merealisasikan keuntungan (falah).

Pemerintah adalah pemegang amanah Allah untuk menjalankan tugas-tugas kolektif dalam upaya mewujudkan kesejahteraan dan keadilan (al-adl wal ihsan) serta tata kehidupan yang baik (hayyah thayyibah) bagi seluruh umat. Pemerintah karenanya adalah khalifullah atau pemegang mandat untuk merealisasikan keuntungan bersifat materi dan inmateri (falah). Sebagai pemegang amanah Tuhan, eksistensi dan peran dari pemerintah ini memiliki landasan yang kokoh dalam Al-Quran dan Sunnah, baik secara eksplisit maupun implisit (Askari et al., 2014). Tanggungjawab untuk membangun kesejahteraan terpundak pada pemimpin, seperti terkandung dalam Hadist Bukhari Muslim yang maksudnya:

"Ibn Umar r.a berkata: Saya telah mendengar Rasulullah SAW bersabda: setiap orang adalah pemimpin dan akan diminta pertanggungjawaban atas 
kepemimpinannya. Seseorang kepala negara akan diminta pertanggung jawaban perihal rakyat yang dipimpinnya. Seorang suami akan ditanya perihal keluarga yang dipimpinnya. Seorang istri yang memelihara rumah tangga suaminya akan ditanya perihal tanggungjawab dan tugasnya. Bahkan seorang pembantu atau pekerja rumah tangga yang bertugas memelihara barang milik majikannya juga akan ditanya dari hal yang dipimpinnya. Dan kamu sekalian pemimpin dan akan ditanya (diminta pertanggungan jawab) dari hal-hal yang dipimpinnya"(Lihat: Imam Nawawi, tt., 303-304 dalam Badi, 2016).

Berdasarkan hadits tersebut dijelaskan bahwa dalam Islam, semua orang yang hidup di muka bumi ini disebut sebagai pemimpin. Karenanya, sebagai pemimpin, mereka semua memikul tanggung jawab, setidaknya atas dirinya sendiri. Akan tetapi, tanggung jawab disini bukanlah semata-mata bermakna melaksanakan tugas, lalu setelah itu selesai serta tidak menyisakan dampak bagi yang dipimpin.

Dalam menjalankan perannya tersebut, pemerintah bertanggung jawab atas tercapainya keadilan dalam masyarakat. Mengenai hal ini, Ibnu Khaldun menyatakan pemaknaan bahwa (Muslim et al., 2019):

"Kekuatan penguasa (al-Mulk) tidak dapat diwujudkan tanpa implementasi syariah, syariah tidak dapat dilaksanakan kecuali oleh penguasa, penguasa tidak dapat memperoleh kekuatan kecuali dari rakyat (ar-Rijal), rakyat tidak dapat berdiri (sejahtera), kecuali dengan kekayaan (al-Maal), kekayaan tidak dapat diperoleh kecuali dengan pembangunan (al-Imarah), pembangunan tidak dapat dicapai kecuali dengan keadilan (al-'Adl), keadilan adalah ukuran (al-Mizan) perhitungan akhirat.“
Berdasarkan pemikiran Ibnu Khaldun, Umer Chapra mengajukan relasi fungsional dalam sistim ekonomi syariah sebagai berikut (Amalia, 2016):

$$
G=f(S, N, W, g \text { dan } j)
$$

dimana keberhasilan suatu Pemerintahan (G/ goverment) merupakan fungsi dari penerapan Syariah (S/syariah) dalam masyarakat (N/ nation) untuk mewujudkan kesejahteraan (W/wealth) dengan menjalankan pembangunan atau pertumbuhan ekonomi (g/growth) dan menegakkan keadilan (j/justice).

\section{Sektor Informal}

Konsep sektor informal pertama kali digunakan oleh Keirt Hard dari University of Manchester pada tahun 1973 yang menggambarkan bahwa sektor informal adalah bagian angkatan kerja di kota yang berada di luar pasar tenaga kerja yang terorganisir. Kemudian konsep informal dikembangkan oleh organisasi buruh dunia (ILO atau International Labour Office) dalam berbagai penelitian di lingkup dunia ketiga. Konsep itu digunakan sebagai salah satu alternatif untuk menangani masalah kemiskinan di dunia ketiga dalam hubungannya dengan problem pengangguran, migrasi dan urbanisasi (Kaur, 2010).

Konsep sektor informal seringkali digunakan untuk menjelaskan bahwa sektor informal dapat mengurangi pengangguran di negara-negara sedang berkembang. Bahkan beberapa pengamat pembangunan di negara yang sedang berkembang memandang sektor informal sebagai strategi alternatif pemecahan masalah keterbatasan peluang kerja. Sektor informal berfungsi sebagai katup pengaman yang dapat meredam ledakan sosial akibat meningkatnya pencari kerja, baik dalam kota maupun pendatang dari desa (Sari, 2016). 
Terwujudnya kehidupan sosial ekonomi seseorang tidak terlepas dari usaha-usaha manusia itu sendiri dengan segala daya dan upaya yang ada serta dipengaruhi beberapa faktor pendorong, antara lain dorongan untuk mempertahankan diri dalam hidupnya dari berbagai pengaruh untuk mengatasi beban hidup dan dorongan untuk mengembangan diri dari kelompok sosial. Semuanya terlihat dalam bentuk hasrat, kehendak, kemauan, baik secara pribadi maupun yang sifatnya kelompok sosial (Pitoyo, 2016).

\section{METODE PENELITIAN}

Penyajian data pada artikel ini sepenuhnya mengikuti alur metode kualitatif melalui analisis deskriptif atas fenomena pedagang kaki-lima yang melakukan aktivitasnya di lokasi penelitian, yaitu di Jl. Cut Nyak Dhien Kota Langsa. Proses pengumpulan data dilakukan melalui tahapan observasi dan depthinterview, dan dokumentasi (Sugiyono, 2016; Fuad et al., 2019; Pratiwi et al., 2021).

Subyek penelitian sebanyak lima (5) orang pelaku usaha yang telah berpengalaman menjalankan usahanya selama satu sampai tiga tahun. Sementara pada pihak Pemerintah Kota selaku pihak pemegang kebijakan yang menguasai banyak informasi terkait regulasi berkenaan pedagang kaki-lima, digunakan dua orang informan yang mewakili instansi/dinas terkait, yaitu dari Disperindag Kota Langsa serta DPKAD Kota Langsa. Karakteristik dari informan dan responden dari penelitian ini terlihat dalam Tabel 1 .

Berdasarkan Tabel 1, karakteristik dari responden sebagai pedagang kaki-lima dalam penelitian ini menunjukkan adanya kesamaan sifat kesamaan, yaitu dari golongan ekonomi lemah, pekerjaan bersifat rutin terjadwal, bukan pekerjaan sampingan, dan menjadikan pekerjaan tersebut untuk menopang ekonomi keluarga. Sementara dari sisi informan adalah lembaga resmi milik pemerintahan kota yang bertanggungjawab atas upaya pemberdayaan ekonomi rakyat melalui program UMKM serta berperan sebagai pengambil kebijakan untuk mengatur lokasi para pedagang kakilima menjajakan dagangannya (Andiny \& Nurjannah, 2018).

Dengan demikian, data yang diperoleh baik dari responden maupun juga informan akan saling menguatkan. Hal ini karena terjadinya sistem mutual symbiosis antara pemerintah yang bermaksud memajukan perekonomian rakyat dengan penyediaan fasilitas yang memadai dan juga para pedagang kaki-lima membayar retribusi dengan tetap menjaga imej keindahan, kenyamanan, ketertiban dan kebersihan kota untuk terus memikat jumlah pengunjung (Reza, 2016).

Tabel 1. Karakteristik Informan dan Responden

\begin{tabular}{clccc}
\hline No. & \multicolumn{1}{c}{ Min } & Jenis Kelamin & Pekerjaan & Peran \\
\hline 1 & Samsul Bahri & Laki-laki & Sektaris Disperindak & Informan \\
2 & Mukhsin & Laki-laki & Staf Disperindak & Informan \\
3 & Ridwan & Laki-laki & Penjual air kelapa & Responden \\
4 & Syahrida & Perempuan & Penjual jeruk peras dan burger & Responden \\
5 & Lia & Perempuan & Penjual cemilan & Responden \\
6 & Rani & Perempuan & Penjual gorengan & Responden \\
7 & Ajo Ujang & Laki-laki & Penjual sate & Responden \\
\hline
\end{tabular}

Sumber: Data diolah, 2020. 
Dalam proses analisis data, unit penting adalah tersedianya informasi yang akurat dari semua pihak baik dari responden, informan dan juga masyarakat (Mastura et al., 2019). Untuk memudahkan proses analisis, data diklasifikasikan untuk menjelaskan beberapa aspek, yaitu: (1) adanya peran sektor informal pedagang kaki-lima terhadap ketersediaan lapangan kerja; (2) adanya prospek pengembangan usaha terhadap pertumbuhan ekonomi keluarga; serta, (3) adanya penambahan sumber pendapatan asli daerah (PAD) melalui pengutipan retribusi.

\section{HASIL ANALISIS}

\section{Peran Sektor Informal bagi Ketersediaan Lapangan Kerja}

Masalah angkatan kerja dan tenaga kerja di Indonesia dalam berbagai sektor yang dilakukan pemerintah sangat membutuhkan tenaga kerja yang mempunyai kualifikasi keahlian tertentu. Berbagai jenis lapangan pekerjaan terbuka setiap waktu di seluruh Indonesia, tetapi pencari pekerjaan jauh lebih banyak dibandingkan kuota yang tersedia.

Banyaknya permasalahan yang dihadapi ketenagakerjaan di Indonesia, diindikasikan antara lain disebabkan oleh tiga hal (Adianto \& Fedryansyah, 2018). Pertama, jumlah angkatan kerja yang tidak seimbang dengan kesempatan kerja, karena jumlah penduduk yang besar akan menghasilkan angkatan kerja yang besar pula. Kedua, mutu tenaga kerja yang relatif rendah dan rendahnya tingkat pendidikan adalah salah satu faktor yang mempengaruhi mutu tenaga kerja Indonesia. Ketiga, persebaran tenaga kerja yang tidak merata dimana sektor ketenagakerjaan di Indonesia juga dihadapkan kepada masalah penyebaran tenaga kerja yang tidak merata.

Badan Pusat Statistik (BPS) mencatat pertumbuhan ekonomi di tahun 2019 sebesar 5,02 persen mengalami perlambatan dibandingkan tahun 2018 sebelumnya sebesar
5,17 persen, dan pada tahun 2017 sebesar 5,07 persen. Kepala BPS pada saat itu, Suhariyanto, mengatakan hal ini terjadi akibat situasi perekonomian global yang melambat. Namun di situasi ekonomi seperti ini terjadi pertumbuhan di di seluruh lapangan usaha, dimana pertumbuhan tertinggi dicapai oleh lapangan usaha jasa lainnya sebesar 10,55 persen (Badan Pusat Statistik, 2020).

Di Indonesia, dalam tiga dekade terakhir jumlah pekerja informal terus menunjukkan peningkatan mulai dari kisaran 25 persen menjadi sebesar 36 persen dan 42 persen dalam rentang waktu per sepuluh tahun (1980-1990-2000). Sebahagian besar pekerja informal khususnya di perkotaan terserap ke dalam sektor perdagangan, diantaranya yaitu sektor perdagangan jalanan atau kaki-lima (Athaillah et al., 2013).

Tipe perdagangan jalanan telah menjadi sebuah alternatif pekerjaan yang relatif cukup populer, terutama di kalangan kelompok masyarakat miskin di area perkotaan. Hal ini terkait dengan mobilitas usaha yang fleksibel, modal yang dibutuhkan relatif kecil dan tidak memerlukan prosedur teknis yang sulit. Bapak Samsul Bahri, Sekretaris Disperindak Kota Langsa, mengemukakan:

"Peran kami selaku pemerintah untuk meningkatkan PAD Kota Langsa salah satunya adalah dengan pemberdayaan Pedagang Kaki-Lima yang berada di Kota Langsa, himbauan dari Walikota Langsa terus membantu masyarakat yang melakukan kegiatan ekonomi. Dari Dinas Perindustrian dan Perdagangan Kota Langsa, kami juga menyediakan fasilitas yaitu dengan pemberian pinjaman sesuai dengan perintah Presiden Republik Indonesia. Modal pinjaman yang diberikan melalui Bank yang ditunjuk yaitu sebesar $R p$. 20.000.000 per pedagang kaki-lima, dengan tujuan untuk membantu kegiatan pedagang kaki-lima”. 
Berkenaan dengan fasilitas-fasilitas pendukung yang disediakan oleh pemerintah, Beliau juga menyampaikan bahwa:

"Dinas Perindustrian dan Perdagangan Kota Langsa dalam hal ini untuk membantu pedagang kaki-lima di Kota Langsa yaitu dengan memberikan fasilitas senyaman mungkin. Untuk tahap awal kami memberikan pelayanan mulai dari lapak penjualan, tenda, dan yang sedang kami usahakan adalah masuknya sarana dan prasarana air besih guna untuk mempermudah pedagang kaki-lima melakukan kegiatan penjualan. Sedangkan untuk akses bagi pengguna pejalan kaki/sepeda motor/ mobil, sedang kami upayakan untuk mengalihkan perjalanannya agar tidak terganggu penjualan tersebut."

Berbagai kebijakan berkaitan dengan penanganan pedagang kaki-lima yang dilakukan oleh Pemerintah Kota Langsa, baik yang bersifat exclusion (penggusuran) maupun inclusion (tendanisasi), sebahagian besar terbukti Pemerintah Kota Langsa masih terus melakukan upaya dalam peningkatan dan pembinaan terhadap pedagang kaki-lima yang mereka adalah penduduk asli Kota Langsa. Hal ini merupakan upaya untuk memfasilitasi tujuan mereka berjualan yaitu memenuhi kebutuhan hidup sehari-hari.

Para pedagang kaki-lima terus dipantau dan memperoleh pembinaan, seperti yang disampaikan oleh Bapak Mukhsin dari Disperindak Kota Langsa sebagai berikut:

"Pemerintah Kota Langsa juga melakukan pembinaan terhadap pedagang kaki-lima contohnya seperti kegiatan seminar yang dilakukan oleh Pemda dan bekerjasama dengan pihak instansi terkait. Hal ini agar masyarakat Kota Langsa khususnya pedagang kaki-lima mengerti dan menguasai tetang konsep dasar penjualan, dan mampu melakukan penataan dari lokasi yang telah ditentukan sebagai salah satu obyek wisata kuliner Kota Langsa yang mesti tertata dengan baik”.

\section{Sistem Tata Kelola Pedagang Kaki-Lima}

Keberadaan pedagang kaki-lima adalah satu fenomena kegiatan perekonomian rakyat kecil baik di kota besar maupun kota kecil. Akhir-akhir ini fenomena penggusuran atas para PKL marak terjadi, bahkan tindakan sewenang-wenang sering terjadi yang berdampak pada rusaknya tatanan kehidupan sosial-ekonomi serta mengusik ketertiban masyarakat di perkotaan. Munculnya istilah Pedagang Kaki-Lima (PKL) ini timbul dari akibat tidak tersedianya lapangan pekerjaan dan tidak didukung oleh sumber daya yang memadai (Handoyo, 2014).

Pedagang Kaki-Lima yang berada di lokasi Jalan Cut Nyak Dhien Kota Langsa merupakan salah satu asset pendapatan bagi Pemerintah Kota Langsa. Namun dalam hal ini pemerintah Kota Langsa harus melakukan pembinaan dan memberi perhatian khusus terhadap pedagang kaki-lima dikarenakan mereka merupakan sumber pendapatan bagi masyarakat Kota Langsa dan sesuai dengan visi dan misi Pemerintah Kota Langsa yang salah satunya adalah bertujuan menciptakan kesejahteraan bagi masyarakatnya. Hal ini sesuai pendapat Bapak Ridwan selaku salah seorang pedagang air kelapa di lokasi itu:

"Selama ini saya selaku pedagang yang berjualan di lokasi sini belum adanya penyediaan akses atau fasilitas yang baik atau memadai. Contohnya saya berjualan disini ya, semua fasilitas kami bawa sendiri dari rumah seperti, tenda, gerobak dan lain-lain. Jadi ya selama ini pemerintah Kota Langsa cuma menyediakan lapak jualan saja”.

Apabila diperhatikan bahwa para pedagang kaki-lima yang berdagang di Jalan Cut Nyak Dhien Kota Langsa adalah penduduk asli Kota Langsa untuk mencari rejeki guna memenuhi kebutuhan hidup diri- 
nya dan keluarganya. Secara umum, pedagang kaki-lima banyak yang berasal dari kalangan keluarga kurang mampu dan anak-anak muda yang belum ada pekerjaan tetap sehingga mereka dengan sendirinya membuka usaha dengan modal sendiri (Permatasari et al., 2014). Seharusnya hal ini menjadi perhatian Pemerintah Kota Langsa dan dinas yang ditunjuk untuk mengelola pedagang kaki-lima yang ada di Kota Langsa. Seperti keluhan Bapak Syahrida selaku pedagang jeruk peras dan burger yang sudah berjualan selama lebih dari dua tahun bahwa selama ia berjualan sampai saat ini, tidak ada yang diberikan oleh pemerintah selain lapak dan itu juga tidak dilengkapi dengan sarana air bersih.

Berkenaan dengan kenyamanan pembeli yang dinilai dapat mempengaruhi daya beli, Ibu Lia selaku pedagang cemilan menyatakan pendapat berikut:

“... dulu kami berjualan di depan pendopo wali kota, kemudian kami dipindahkan ke Jalan Cut Nyak Dhien. Pastinya setelah kami dipindahkan pendapatan kami sedikit berkurang, karena pembeli memilih lokasi yang bagus untuk santai, lagi pula disini terlalu sempit sangat mengganggu akses bagi pengguna jalan. Harapan kami pemerintah Kota Langsa kedepannya menyediakan tempat yang baru lebih nyaman dan terjangkau".

Demikian juga pendapat Ajo Ujang, seorang pedagang sate yang menaruh harapan kepada Pemerintah Kota:

"Harapan kami kepada Pemerintah Kota Langsa untuk melihat-lihat kami pedagang kaki-lima ini, karena secara tidak langsung kami disini juga membantu pemerintah dalam mengatasi pengangguran. Coba bayangkan saja pak kami yang berjualan di sini sudah terekrut sejumlah pekerja. Contoh seperti saya saja mempekerjakan dua orang karyawan, kemudian kami disini membayar retribusi setiap sorenya ada yang mengutip. Adapun besaran uang retribusi yang dikutip Rp. 2.000,- untuk retribusi dan Rp. 1.000,- untuk sampah. Namun penyediaan akses lainnya belum ada sampai saat ini, jadi masih sangat serba kekurangan".

Dengan demikian, keberadaan pedagang kaki-lima di wilayah Kota Langsa dalam perkembangannya, telah menggunakan area atau jalan fasilitas umum yang menimbulkan gangguan ketentraman, ketertiban masyarakat, kebersihan lingkungan, serta kelancaran lalu lintas sehingga dinilai perlu dilakukan pengaturan agar tercipta tertib sosial maupun ketentraman pada para anggota masyarakat (Wijayaningsih, 2018).

\section{Prospek Retribusi dari Pedagang Kaki- Lima}

Kemampuan satu wilayah untuk tumbuh secara cepat sangat ditentukan oleh berbagai faktor ekonomi yang satu sama lainnya juga saling berkaitan. Faktor-faktor yang memiliki peran sebagai penentu pertumbuhan ekonomi wilayah tersebut perlu diketahui secara terperinci beserta sifatnya. Perhatian terhadap pertumbuhan ekonomi wilayah semakin meningkat dalam era otomoni daerah. Hal ini dinilai cukup logis karena dalam era otonomi saat ini masing-masing daerah berlomba agar mampu meningkatkan pertumbuhan ekonomi daerahnya bagi upaya mendorong penciptaan ataupun perbaikan kemakmuran masyarakat setempat (Nuraini, 2017).

Berkenaan dengan dampak pengutipan retribusi terhadap pelayanan kepada pedagang kaki-lima, Bapak Samsul Bahri mewakili Disperindag Kota Langsa merespon:

"Untuk perhatian khusus terhadap pedagang kaki-lima, kami selaku pemerintah melalui Dinas Perindustrian dan Perdagangan Kota Langsa selalu menampung aspirasi dari pedagangpedagang kaki-lima yang ada di Kota 
Langsa guna untuk memberikan pelayanan yang baik demi kemajuan para pedagang. Namun ini perlahanlahan kami kelola dengan baik”.

Pada dasarnya, peran Pemerintah Kota Langsa dalam proses pelaksanaan program pembangunan ekonomi rakyat harus memiliki dasar rasionalitas yang kokoh. Dalam lingkup pandangan Islam, peran pemerintah didasari beberapa argumentasi (Habibullah, 2017), yaitu: (a) Derivasi dari konsep kekhalifahan; (b) Kosekuensi adanya kewajiban-kewajiban kolektif (fard al-kafiyah); serta, (c) Adanya kegagalan pasar dalam merealisasikan falah.

Qanun Kota Langsa Nomor 06 Tahun 2018 berkenaan dengan Pedagang KakiLima) menerangkan kegiatan pedagang kakilima merupakan salah satu perdagangan sektor informal yang perlu diberdayakan guna menunjang pertumbuhan ekonomi masyarakat sekaligus sebagai salah satu pilihan dan penyediaan barang dagangan yang dibutuhkan oleh masyarakat dengan harga yang relatif terjangkau. Dalam persoalan ini, Sekretaris Disperindag menjelaskan lebih lanjut sebagai berikut:

"Dalam hal pemberdayaan Pedagang Kaki-Lima di Kota Langsa, kami selaku pemerintah ada juga memberikan fasilitas terutama fasilitas KUR bagi UMK yang bekerja sama dengan beberapa Bank di Kota Langsa, diantaranya Bank BRI, Mandiri dan Bank BNI, dan kerjasama itu atas dasar dar Peraturan Menteri Bersama tentang UMKM dan diteruskan atas dasar wewenang Walikota Langsa. Fasilitas itu pada tahun 2017 memberikan penyaluran KUR dari Bank BRI sebesar Rp. 76 Milyar untuk pengembangan Pedagang Kaki-Lima atau UMK di Kota Langsa. Sedangkan untuk sarana pada tahun 2016 melalui peraturan Walikota Langsa, kami juga memberikan fasilitas seperti: tenda yang berukuran $3 \times$ 3/unit untuk UMK, dan kemudian kami juga menyediakan air bersih dan meteran listrik. Salah satunya untuk PAD Kota Langsa yang bersumber dari pedagang kaki-lima ini yaitu retribusi yang dikutip perharinya antara lain $R p$. 2.000 retribusi dan $R p$. 2.000 sampah atau perbulan nya sebesar Rp. 3.500.000 - Rp. 4.000 .000 dan ini disetorkan ke Disperindag dan nantinya disetorkan ke bendahara daerah Kota Langsa”.

Dari permasalahan yang telah diuraikan itu, pemerintah merupakan pemegang amanah Allah untuk menjalankan tugas-tugas kolektif dalam mewujudkan tata kesejahteraan dan keadilan serta tata kehidupan yang baik bagi seluruh masyarakat. Pemerintah bisa memiliki peranan penting dalam menjalankan tugas dan amanahnya, hal ini dikarenakan kemungkinan masyarakat gagal untuk menjalankannya atau tidak dapat melaksanakannya dengan baik. Kemungkinan kegagalan masyarakat dalam menjalankan kegiatannya dinilai disebabkan oleh beberapa faktor (Charis et al., 2020), yaitu: (a) asimetri dan kekurangan informasi; (b) pelanggaran moral; serta, (c) kekurangan sumber daya atau kesulitan teknis.

\section{Pembahasan}

Kota Langsa sebagai Kota Jasa

Kota Langsa ditetapkan pada tanggal 17 Oktober 2001 berdasarkan Undang-Undang Nomor 3 tanggal 21 Juni 2001, dan saat ini memfokuskan diri sebagai kota pendidikan, perdagangan, kuliner/makanan, dan wisata (Hibabullah et al., 2019; Nugroho, 2019). Kota Langsa berlokasi sangat dekat dengan Kota Medan, yaitu ibukota Propinsi Sumatera Utara, sehingga menempatkan Kota Langsa sebagai kota yang strategis dan ramai imigran (Miswar \& Ramadhani, 2019). Kota Langsa memiliki sentra wisata kuliner bernama CBD (Central Business District) Kuliner Langsa) yang terletak di Jalan Teuku Nyak Arief dan Jalan Cut Nyak Dhien (Kristiana et al., 2018). 
Pengembangan Kota Langsa sebagai destinasi wisatawan lokal dan manca negara tidak terlepas dari kemampuan pemerintah kota dalam melaksanakan tupoksinya sesuai dengan visi dan misinya. Visi Kota Langsa adalah "Langsa Kota Jasa dan Industri yang maju dan Islami”, sementara misi yang dimiliki diantaranya adalah melanjutkan pembangunan infrastruktur guna mendukung percepatan pembangunan dan pengembangan wilayah, serta meningkatkan kesejahteraan ekonomi masyarakat (Diskominfo Kota Langsa, 2017).

\section{Sistem Tata Kelola yang Dinamis dan Modern}

Mobilitas penduduk menuju daerah perkotaan di Indonesia semakin meningkat dengan pesat, dimana hal ini ditunjukkan oleh angka pertumbuhan penduduk kota yang sangat tinggi. Bila sebuah kota menjadi pusat pembangunan sektor formal, maka kota itu dipandang lebih menjanjikan bagi masyarakat desa. Salah satu sektor informal yang menjadi fenomena di perkotaan adalah pedagang kakilima (PKL). Dengan adanya keterbatasan lapangan kerja di sektor formal, pedagang kaki-lima menjadi pilihan yang mudah untuk bertahan hidup. Hal tersebut sesuai dengan ciri-ciri dan sektor informal yaitu mudah dimasuki, disebabkan usaha tersebut memiliki skala relatif kecil (Zulfa, 2016).

Namun untuk pelaksanaannya terhadap pedagang kaki-lima yang ada di Kota Langsa, dari tahun ke tahun dinilai terus mengalami peningkatan. Bagaimanapun juga, pemerintah dihaarapkan terus melakukan pembinaan salah satunya adalah dengan memberikan kegiatan seminar maupun pemberian bantuan permodalan. Hal ini dilakukan dengan tujuan untuk membantu dalam proses perdagangan, sebab penghasilan yang diperoleh melalui berjualan itu adalah sumber utama mata pencaharian bagi mereka.
Pemerintah Kota Langsa dan jajarannya ataupun dinas terkait yang menangani permasalahan PKL ini juga diharapkan terus melakukan berbagai upaya pembenahan dan pemberian fasilitas yang baik. Hal ini karena tanpa disadari para pedagang kaki-lima ini membantu program pemerintah berkenaan dengan pengentasan pengangguran maupun kemiskinan. Target Pemerintah Kota Langsa melalui pedagang kaki-lima adalah menjadikan Kota Langsa sebagai destinasi Wisata Kuliner yang mengadopsi nilai-nilai religi dan nilai-nilai budaya lokal.

Berkaitan dengan aspek sistem tata kelola yang dinamis dan modern, direkomendasikan kepada pihak pemerintah Kota Langsa untuk melakukan sejumlah upaya pengembangan tata kelola wisata kuliner tradisional secara modern dengan terus memperhatikan kondisi PKL yang ada di Kota Langsa. Rekomendasi ini diberikan mengingat PKL yang ada di Kota Langsa dilihat dari segi fasilitas belumlah sangat memadai, misalnya seperti fasilitas tempat berjualan yang tidak nyaman karena terlalu sesak dengan pengguna kenderaan motor dan mobil, serta kelemahan pada sarana air bersih maupun tempat pembuangan sampah (Anon, 2018).

\section{Pembinaan dan Pengembangan Usaha}

Penertiban para pedagang kaki-lima dapat dilakukan secara terprogram melalui pembinaan dan pengembangan usaha dengan berbagai program pelatihan keterampilan usaha. Sebaiknya pemerintah Kota Langsa untuk lebih memberdayakan mereka, yaitu para pedagang kaki-lima yang terletak di Jalan Cut Nyak Dhien. Apabila target pemerintah setempat ingin menjadikan obyek wisata kuliner sebagai salah satu daya tarik untuk berkunjung ke Kota Langsa, maka semestinya Pemerintah Kota Langsa terus memperhatikan kondisi pedagang kaki-lima. 
Hal ini terutama dalam pemberian pinjaman atau sarana dan prasarana kepada pedagang tersebut, sehingga mereka kondisinya makin lebih baik lagi (Syamsulbahri, 2018).

Keindahan lokasi tempat kegiatan usaha masih terganggu dan sangat tidak nyaman, karena tidak didukung ketersediaan sarana dan fasilitas penunjang usaha yang asri dan seragam dari segi warna, penempatan serta bentuk dari produk usaha. Kondisi ini terjadi karena mereka secara individu merancang sendiri, padahal sebaiknya pihak Disperindag yang mengatur agar sesuai dengan keserasian dan keasrian Kota Langsa sebagai kota jasa. Kondisi sisi ruas jalan juga sering digunakan untuk parkir, sehingga membuat jalan macet dan tentunya sangat tidak nyaman (Petersen \& Schäfer, 2004).

Selain pembinaan di bidang pengelolaan keuangan serta pemberdayaan kapasitas keahlian usaha, mereka juga perlu adanya pembinaan mental spiritual untuk lebih menjamin ketentraman jiwa. Jika diamati dan ditelusuri bahwa aktivitas usaha mereka mulai dari jam 15.00 sampai 24.00 WIB, tentu saja banyak sisi yang terabaikan untuk mencapai kepuasan yang ideal. Mereka berharap ada perhatian khusus terhadap mereka, karena mereka berjualan ini salah satunya adalah untuk menyambung tujuan hidup serta mencukupi kebutuhan sehari-hari, baik untuk kebutuhan belanja maupun kebutuhan anak sekolah dan juga pengajian agama islam di lembaga non formal (Handoyo, 2014).

Seorang pedagang memberi pengakuan bahwa ia sudah hampir lima tahun berjualan, dan selama itu yang ia butuhkan selaku pedagang ini adalah akses penyediaan tempat yang lebih baik, ingin diberikan pembiayaan untuk pembuatan gerobak dan tenda yang layak. Hal ini karena jika ia berharap kepada putaran keuntungan dari penjualan usaha maka tidaklah cukup bagi dirinya untuk membuat gerobak dagang yang lebih baik lagi. Harapannya adalah adanya pemberian pinjaman modal dengan tingkat suku bunga yang lebih rendah, karena kalau bunga terlalu tinggi maka para pedagang pun tidak akan mampu untuk menutupinya.

Berdasarkan hasil pemantauan di lokasi juga ditemukan bahwa ada pihak ketiga yang menawarkan pembiayaan dan bahkan ada yang sudah mengambil jasa pembiayaan informal yang dilakukan oleh para rentenir atas nama koperasi untuk membantu usaha mereka. Tentu saja model pembiayaan yang ditawarkan menyalahi dari prinsip-prinsip syariah, seperti mengandung unsur riba dan gharar (Saepudin \& Cahyani, 2016; Pratiwi et al., 2021). Namun demikian berdasar fakta lapangan, mereka lakukan peminjaman pada rentenir itu karena ada keterpaksaan untuk keberlangsungan usaha mereka.

\section{PKL dan Retribusi}

Pemerintah Kota Langsa juga sangat diuntungkan jika upaya-upaya pemberdayaan dan pengembangan pedagang kaki-lima dilakukan secara terprogram sesuai visi dan misi Kota Langsa sebagai kota jasa. Jika pendapatan sumber ekonomi dari warga kota mengalami peningkatan maka berdampak pada meningkatnya pendapatan daerah, dan mereka sebagai pelaku usaha di lokasi yang telah ditentukan pemerintah akan membayar retribusi sebagai sumber pendapatan asli daerah (PAD).

Untuk membantu peningkatan UMKM di Kota Langsa, dalam hal ini pemerintah melalui Peraturan Menteri Bersama tentang izin UMKM atas dasar surat Keputusan Walikota Langsa/Kecamatan sudah dijalankan dengan baik. Program pengembangan KUR (Kredit Usaha Rakyat) dinilai mampu mengatasi masalah permodalan dan juga adanya pengawasan bersama. Pada tahun 2017 KUR (Kredit Usaha Rakyat) melalui Bank BRI Kota Langsa mendapatkan bantuan 
dana sebesar Rp. 76 milyar. Sedangkan pada tahun 2016 sebelumnya melalui peraturan Walikota Langsa, bantuan yang diberikan berupa: tenda ukuran 3 x 3 per 1 UMKM, air bersih, dan meteran listrik. Program ini tidak terlepas dari pantauan Disperindag Kota Langsa untuk memberikan reward kepada pedagang berprestasi pada event ulang tahun Kota Langsa (Andiny \& Nurjannah, 2018).

Retribusi yang berasal dari pengutipan pedagang kaki-lima pada setiap harinya dengan ketentuan besaran Rp. 2.000., disetor kepada kantor Dinas Perindustrian dan Perdagangan Kota Langsa. Selanjutnya, untuk setiap bulannya retribusi tersebut disetorkan kembali ke kantor Dinas Keuangan dan Pendapatan Asset Daerah Kota Langsa. Pendapatan retribusi ini merupakan salah satu sumber devisa bagi Kota Langsa (Berwulo et al., 2017).

\section{SIMPULAN}

Aktivitas pedagang kaki-lima adalah salah satu alternatif mata pencaharian bagi masyarakat Kota Langsa yang tidak dapat memasuki sektor formal karena pekerjaan tersebut mudah dimasuki, tidak membutuhkan pendidikan tinggi, tidak membutuhkan modal besar, namun dapat menghasilkan pendapatan yang kadang melebihi sektor formal.

Lokasi pedagang kaki-lima yang telah ditentukan oleh Pemerintah Kota Langsa termasuk dalam penataan keindahan kota, sehingga pola penyebaran aktivitas keramaian kota terpusat pada lokasi tertentu yang dapat menjamin ketertiban dan kenyamanan para pengunjung. Meskipun telah dibuat tentang penataan pedagang kaki-lima, namun baik pedagang kaki-lima maupun masyarakat menganggap perlu diadakan pengaturan yang lebih lanjut untuk mendisiplinkan pedagang kaki-lima tersebut yang melakukan penjualan dan tidak menambah lagi space yang menyalahi ukuran yang disetujui.
Berdasarkan simpulan tersebut, maka dinyatakan beberapa rekomendasi kepada pihak pemerintah Kota Langsa. Rekomendasi pertama, berkaitan dengan akses sarana dan prasarana sebaiknya Pemerintah Kota Langsa membantu para pedagang kaki-lima untuk memberikan fasilitas yang baik, dikarenakan pedagang kaki-lima ini bisa dijadikan sebagai salah satu wisata kuliner di Kota Langsa, dan dapat mendongkrak pertumbuhan ekonomi dikalangan masyarakat bawah. Rekomendasi kedua adalah agar dilakukan peninjauan atas pinjaman modal KUR yang diberikan oleh pemerintah melalui peraturan menteri dan ditetapkan dalam peraturan Walikota Langsa untuk dapat mendata kembali para pedagang yang membutuhkan modal dan dipinjamkan secara mudah melalui Bank Syariah, serta ada pihak yang melakukan pendampingan usaha dan pengawasan secara prinsip Syariah bagi pedagang kaki-lima.

Rekomendasi ketiga adalah perlu adanya penelitian lanjutan terhadap dampak negatif pertumbuhan pedagang kaki-lima yang terkonsentrasi di satu titik, sehingga menimbulkan kemacetan lalu lintas, suasana tidak nyaman, polusi udara, dan masalah sosial lainnya. Kondisi demikian menuntut Pemerintahan Kota untuk menyediakan lebih banyak lagi ruang terbuka bagi pedagang kaki- lima untuk berdagang. Tentu saja alternatif lokasi dimaksud semakin memperindah Kota Langsa sebagai tujuan wisata.

\section{REFERENSI}

Adianto, J., \& Fedryansyah, M. (2018). Peningkatan kualitas tenaga kerja dalam menghadapi Asean Economy Community. Focus: Jurnal Pekerjaan Sosial, 1(2), 77-86. doi: 10.24198/ focus.v1i2.18261.

Aliyah, I. (2017). Pemahaman konseptual pasar tradisional di perkotaan. Cakra Wisata Jurnal Pariwisata dan Budaya, 
18(2), 1-16. Retrieved from https:// jurnal.uns.ac.id/cakra-wisata/article/ view/34367.

Amalia, E. (2016). Transformasi nilai-nilai ekonomi Islam dalam mewujudkan keadilan distributif bagi penguatan usaha kecil mikro di Indonesia. AlIqtishad: Journal of Islamic Economics, 3(1), 65-92. doi: 10.15408/aiq.v3i1. 2497.

Andiny, P., \& Nurjannah. (2018). Analisis pemberdayaan usaha mikro kecil dan menengah (UMKM) sebagai upaya penanggulangan kemiskinan di Kota Langsa. Jurnal Serambi Ekonomi dan Bisnis, 5(1), 31-37. Retrieved from http://ojs.serambimekkah.ac.id/serambiekonomi-dan-bisnis/article/view/674/ 614.

Anon. (2018). Kuliner sebagai pendukung industri pariwisata berbasis kearifan lokal. Teknobuga, 6(1), 1-9. doi: 10.1529/jtbb.v6i1.16667.

Arsyad, L. (2015). Ekonomi pembangunan dan pembangunan ekonomi. Ekonomi Pembangunan Berkelanjutan, 1-37. Retrieved from https://www.pustaka.ut. ac.id/lib/wp-content/uploads/pdfmk/ ESPA4324-M1.pdf.

Askari, H., Iqbal, Z., \& Mirakhor, A. (2014). Understanding development in an Islamic framework. Islamic Economic Studies, 22(1), 1-36. doi: 10.12816/ 0004129.

Athaillah, Hamzah, A., \& Masbar, R. (2013). Faktor-faktor yang mempengaruhi pertumbuhan ekonomi Provinsi Aceh. Jurnal Ilmu Ekonomi: Program Pascasarjana Unsyiah, 1(3), 1-13. Retrieved from http://jurnal.unsyiah. ac.id/MIE/article/view/4529/3904.

Badan Pusat Statistik. (2020). Keadaan ketenagakerjaan Indonesia Februari 2020. Retrieved from https://www.bps. go.id/.

Badi, J. A. (2016). Commentary of forty hadiths of An Nawawi. Islamic Learning Foundation, 1-220. Retrieved from https://ahadith.co.uk/downloads/
Commentary_of_Forty_Hadiths_of_ An-Nawawi.pdf.

Berger, P. G., Ofek, E., \& Yermack, D. L. (1997). Managerial entrenchment and capital structure decisions. Journal of Finance, 52(4), 1411-1438. doi: 10.1111/j.1540-6261.1997.tb01115.x.

Berwulo, L. L. D., Masinambow, V. A. J., \& Wauran, P. C. (2017). Analisis pendapatan asli daerah (PAD) di Kota Jayapura. Jurnal Berkala Ilmiah Efisiensi, 17(1), 22-33. Retrieved from https://studylibid.com/doc/2411385/ana lisis-pendapatan-asli-daerah--pad--dikota---e.

Charis, M., Ammar, M., Wijokongko, D., \& Al-Hafizd, M. F. (2020). Kategori kepemimpinan dalam Islam. Jurnal Edukasi Nonformal, 1(2), 171-189. Retrieved from https://garuda.ristek brin.go.id/documents/detail/1744573.

Diskominfo Kota Langsa. (2017). Visi dan Misi Pemerintahan Kota Langsa. Retrieved from https://www.langsakota. go.id/visi-dan-misi/.

Egerer, M., Langmantel, E., \& Zimmer, M. (2016). Gross domestic product. in Regional Assessment of Global Change Impacts: The Project GLOWA-Danube, 147-152. doi: 10.1007/978-3-31916751-0_17.

Ersina, S., Rahayu, I., \& Yuliana. (2017). Jalur pedestrian sebagai salah satu fasilitas perkotaan. National Academic Journal of Architecture. 4(1), 57-65. doi: 10.24252/nature.v4ila7.

Fuad, M., Sudarma, M., \& Irianto, G. (2019). Exploration of obstacles faced by successors in the intergenerational transition process of family business. Journal of Applied Management (JAM), 17(1), 20-29. doi: 10.21776/ub.jam. 2019.017.01.03.

Habibullah, E. S. (2017). Hukum ekonomi syariah dalam tatanan hukum nasional. Al-Mashlahah: Jurnal Hukum Islam dan Pranata Sosial, 5(9), 691-710. doi: 10.30868/am.v5i09.190. 
Handoyo, E. (2014). Kontribusi modal sosial dalam meningkatkan kesejahteraan pedagang kaki lima pascarelokasi. KOMUNITAS: International Journal of Indonesian Society and Culture, 5(2), 729-736. doi: 10.15294/komunitas. v5i2.2743.

Hanifullah, H. (2012). Membangun sistem ekonomi umat berbasis syariah. Epistemé: Jurnal Pengembangan Ilmu Keislaman, 7(2), 267-292. doi: 10.21274/epis.2012.7.2.267-292.

Hibabullah, A., Pranada, R. H., Adipraja, F. M., Nugroho, S. A., \& Arafad, Y. (2019). Pembangunan aplikasi explore wisata di Kota Langsa. Majalah Ilmiah UNIKOM, 17(1), 91-100. doi: 10.34010/miu.v17i1.2241.

Kaur, A. (2010). Labour migration in Southeast Asia: Migration policies, labour exploitation and regulation. Journal of the Asia Pacific Economy, 15(1), 6-19. doi: 10.1080/13547860903 488195.

Kristiana, Y., Suryadi, M. T., \& Sunarya, S. R. (2018). Eksplorasi potensi wisata kuliner untuk pengembangan pariwisata di Kota Tangerang. Khasanah Ilmu Jurnal Pariwisata dan Budaya, 9(1), 18-23. doi: 10.31294/khi.v9i1.3604.

Mastura, M., Sumarni, M., \& Eliza, Z. (2019). Peranan infomasi akuntansi terhadap keberhasilan UMKM di Kota Langsa. Jurnal Ekonomi dan Bisnis Islam, 4(1), 20-33. doi: 10.32505/v4i1.1248.

Miswar \& Ramadhani, T. (2019). Pengaruh faktor-faktor demografi terhadap pertumbuhan ekonomi di Kota Langsa. Jurnal Samudra Ekonomika, 3(2), 164174. doi: 10.0123/jse.v3i2.1890.

Muslim, M. B., Saepullah, S., \& Widayatsari, A. (2019). Political economy from the perspective Ibn Khaldun. Al-Iqtishad: Jurnal Ilmu Ekonomi Syariah, 11(1), 59-74. doi: 10.15408/aiq.v11i1. 13341.

Nasution, A. P. (2016). Pemberdayaan sektor ekonomi informal: Suatu tinjauan empiris. Jurnal Dimensi, 4(2), 1-7. doi: $10.33373 /$ dms.v4i2.40.
Nugroho, S. A. (2019). Pembangunan aplikasi explore wisata di Kota Langsa. Majalah Ilmiah UNIKOM, 17(1), 91-100. doi: 10.34010/miu.v17i1.2227.

Pratiwi, N. R., Prajawati, M. I., \& Basir S. (2021). Kredit rentenir dan silaturahmi. Jurnal Samudra Ekonomi dan Bisnis, 12(1), 102-116. doi: 10.33059/jseb. v12i1.2296.

Nuraini, I. (2017). Kualitas pertumbuhan ekonomi daerah kabupaten/kota di Jawa Timur. Prosiding, Seminar Nasional \& Call For Paper, FEB Unikama "Peningkatan Ketahanan Ekonomi Nasional dalam rangka Menghadapi Persaingan Global", Malang, 17 Mei, 79-93. Retrieved from https:// docplayer.info/47864925-Kualitaspertumbuhan-ekonomi-daerahkabupaten-kota-di-jawa-timur.html.

Parimin \& Putra, M. U. M. 2018. Perekonomian Indonesia dalam era globalisasi ASEAN. Jurnal Wira Ekonomi Mikroskil: JWEM, 8(1), 1-12. Retrieved from https://mikroskil.ac.id/ejurnal/ index.php/jwem/article/view/466.

Permatasari, A., Putro, U. S., \& Nuraeni, S. (2014). Strategic analysis relocating street vendor through 3D negotiation case study: Street vendor Surakarta, Indonesia. Procedia - Social and Behavioral Sciences, 115, 436-443. doi: 10.1016/j.sbspro.2014.02.451.

Petersen, R., \& Schafer, C. (2011). Perencanaan tata ruang kota dan transportasi perkotaan. Eschborn, Germany: Deutsche Gesellschaft fijr Internationale Zusammenarbeit (GIZ). Retrieved from http://sutp.transportnama.org/files/contents/documents/reso urces/A_Sourcebook/SB2_Land-UsePlanning-and-Demand-Management/ GIZ_SUTP_SB2a-Land-use-Planningand-Urban-Transport_ID.pdf.

Pitoyo, A. J. (2016). Dinamika sektor informal di Indonesia: Prospek, perkembangan, dan kedudukannya dalam sistem ekonomi makro. Populasi, 18(2), 129-146. doi: 10.22146/jp.12081. 
Prastowo, P. (2016). Analisis pengaruh pertumbuhan ekonomi terhadap penggunaan lahan perkotaan pendekatan spatial econometrics: Studi kasus perkotaan DIY. (2011). Jurnal Ekonomi \& Studi Pembangunan, 17(1), 22-30. doi: 10.18196/jesp.17.1.2458.

Qanun Kota Langsa Nomor 6 Tahun 2018 tentang Rencana Pembangunan Jangka Menengah Daerah Kota Langsa Tahun 2017-2022. Pemerintah Kota Langsa.

Reza, A. (2016). Penataan ruang terbuka publik sebagai jalur pedestrian mall di Kota Langsa (Studi kasus jalan rel kereta api Kota Langsa). ETD Unsyiah. Retrieved from https://etd.unsyiah. ac.id/index.php?p=show_detail\&id=18 573.

Saepudin, E., \& Cahyani, P. D. (2016). Strategi mempersempit ruang gerak rentenir melalui kelompok masyarakat berbasis modal sosial (Studi kasus di Kampung Rahayu Purwokerto). Islamadina, 17(2), 57-70. doi:10.30595/ islamadina.v0i0.1326.

Safuwan. (2007). Gaya hidup, konsumerisme dan modernitas. Jurnal SUWA Universitas Malikussaleh, 5(1), 38-46. Retrieved from http://repository.unimal. ac.id/id/eprint/1342.

Sari, N. P. (2016). Transformasi pekerja informal ke arah formal: Analisis deskriptif dan regresi logistik. Jurnal Ekonomi Kuantitatif Terapan, 9(1), 2836. doi: 10.24843/JEKT.2016.v09. i01.p03.

Sugiyono. (2016). Memahami penelitian kualitatif. CV. Alfabeta.

Syahputra, R. (2017). Analisis faktor-faktor yang mempengaruhi pertumbuhan ekonomi di Indonesia (1990-2016). Jurnal Samudra Ekonomika, 1(2), 183191. Retrieved from https://ejurnal unsam.id/index.php/jse/article/downloa $\mathrm{d} / 334$.
Syamsulbahri, D. (2018). UMKM dalam perspektif pembiayaan inklusif di Indonesia. Jurnal Ekonomi Pembangunan, 26(1), 59-76. doi: 10.14203/JEP.26.1.2018.59-76.

Wijayaningsih, R. (2018). Keterkaitan pedagang kaki lima terhadap kualitas dan citra ruang publik di koridor kartini Semarang pada masa prapembongkaran (Studi kasus: Penggal Jl. dr. Cipto - Jl. Barito). Vitruvian: Jurnal Arsitektur, Bangunan, dan Lingkungan, 7(3), 185-200. Retrieved from https:// publikasi.mercubuana.ac.id/index.php/v irtuvian/article/view/3780.

Yunus, M., \& Insani, A. (2017). Tata kelola pedagang kaki lima di Kota Makassar (Studi kasus pedagang pisang epe' di Pantai Losari). JAKPP (Jurnal Analisis Kebijakan dan Pelayanan Publik), 3(1), 23-36. doi: 10.31947/ jakpp.v3i1.4064.

Zaman, S. (2017). Pola konsumtif masyarakat urban dalam perspektif semiotik dan budaya. Paradigma: Jurnal Kajian Budaya, 7(1), 40-49. doi: 10.17510/ paradigma.v7i1.138.

Zulfa, A. (2016). Pengaruh pertumbuhan penduduk dan pertumbuhan ekonomi terhadap tingkat pengangguran di Kota Lhokseumawe. Jurnal Visioner \& Strategis, 5(1), 13-22. Retrieved from https://jurnal.unimal.ac.id/visi/article/do wnload/226/179. 